\title{
LEICESTER AND SMALLPOX: THE LEICESTER METHOD
}

\author{
by
}

\author{
STUART M. F. FRASER*
}

\section{INTRODUCTION}

A SYSTEM OF dealing with smallpox was developed in Leicester in the 1870 s. This system achieved such notoriety that by the 1890 s it was referred to as the Leicester Method, and Leicester was considered unique in its management of smallpox. ${ }^{1}$ I would like first to describe the evolution of the Leicester Method, and second to discuss and analyse some of the reasons for its development. Here I shall refer particularly to Leicester's anti-compulsory vaccinationists, who have previously been suggested as being primarily responsible for the system's development there.

\section{THE LEICESTER METHOD}

The essentials of the method were prompt notification of a case of smallpox to the Medical Officer of Health, isolation of all cases in the town's Fever and Smallpox Hospital, and quarantine for all the immediate contacts of the original case. The premises were thoroughly disinfected, and latterly all quarantinees were financially compensated for time lost from work. The method, originally formulated in 1877, and modified in 1893, made no specific reference to the use of vaccination. This was a problem to be dealt with by the Board of Guardians and the government rather than the town's Sanitary Committee through whose agency the method was developed.

Various histories of Leicester mention the method, and all attribute its development to the spirit of non-conformity and the local anti-compulsory vaccinationist movements. "They [the anti-vaccinationists] argued their arguments so strongly and coherently as to erect them into a system which came to be known widely as the Leicester Method."2

* Stuart M. F. Fraser, M.B., B.S., M.R.C.G.P., 8 Westminster Road, Leicester.

Note on sources: Town Council Minutes, Sanitary Committee Minutes, Fever Hospital Minutes, and Poor Law Union Minutes - these are all available for study at the Leicestershire Record Office, New Walk, Leicester.

Annual health reports, pamphlets on Leicester, Leicester Daily Post, and Leicester Weekly Post - these are all available for study in The Leicestershire Collection, Leicestershire Libraries and Information Service, Bishop Street, Leicester.

Leicester Medical Society Minutes may be consulted in the Rare Books Room, Clinical Sciences Library, Royal Infirmary, Leicester.

1 Royal Commission, Vaccination and its results, London, New Sydenham Society, 1898, p. 269. R. M. MacLeod, 'Law, medicine and public opinion; the resistance to compulsory health legislation 1870-1907', Public Law, 1967, pt. I, p. 107-pt. II, p. 189.

2 J. Simmons, Leicester past and present, vol 2: Modern city, London, Methuen, 1974, pp. 17-19. Also, "The agitation [anti-vaccinationists] was important to the history of public health, for it was largely the 


\section{HOSPITAL ACCOMMODATION}

The first requirement for the development of the method was a hospital that would admit smallpox cases. Generally, smallpox and fever cases were singled out and excluded from hospitals, although occasionally local "pest-houses" or "houses of recovery" may have been provided. ${ }^{3}$ Before 1803 there was no provision for these cases in Leicester, but in that year the Leicester Infirmary (founded 1771) provided separate ward accommodation for fever cases occurring in existing in-patients. In 1820 the Infirmary opened a twenty-bed "House of Recovery from Contagious Fever" for cases referred by subscribers, mostly cases of typhus. 4 Other accommodation was provided on a temporary basis - for example, the Board of Guardians converted the Bridewell into a hospital for paupers sick with fever - but no permanent provision was made until 1880.5

From 1853 onwards various residents suggested that permanent provision should be made for fever cases, particularly smallpox. Not surprisingly, these pleas were especially vociferous during epidemics. However, the high capital cost of such a venture and its spasmodic use did not greatly commend it. 6 It was not until 1870, when a scarlet fever epidemic was at its height and smallpox threatened, that the various local organizations and individuals came to a final decision. The Town Council undertook to build a fever hospital, for the townspeople only, on its own land on the outskirts of the town. Even then, due to the Council's prevarication during building operations, a temporary hospital had to be provided in the built-up area in 1871. The "permanent" hospital - the Borough Fever and Smallpox Hospital, Freake's Ground - was opened in 1872 , but was quickly found to be too small. It was rapidly expanded during the smallpox epidemic so that the original plan for a 36-bed, three-ward hospital finished as a 108-bed, seven-ward hospital with administrative block, gatehouse, and surrounding brick wall. ${ }^{7}$ This hospital was not closed at the end of the epidemic, and it was altered internally to cope with two to three of the following different types of fever or infectious disease at any one time: smallpox, scarlet fever, erysipelas, measles, and cholera. ${ }^{8}$

resistance to compulsory vaccination that led to the elaboration at Leicester of a new method of dealing with Smallpox." R. A. McKinley and C. T. Smith, Victorian county history, Leicester, vol. 4, London, Oxford University Press, 1958, pp. 251-302.

3 For the history of fever hospital provision in England and Wales see Local Government Board 10th report, infectious diseases supplement, (c. 3290) XXX Pt. II, London, H.M.S.O., 1882, pp. i-iii.

4 E. R. Frizelle and J. D. Martin, The Leicester Royal Infirmary 1771-1971, Leicester No. 1 Hospital Management Committee, 1971, p. 96.

5 The Guardians made some temporary provision in 1846-47, but not until 1880 did they build an infectious diseases ward at the Union Workhouse. A. Temple Patterson, Radical Leicester, Leicester, University College, 1954, p. 375. Building plans, Leicester Record Office, Leicester Poor Law Union, April 1880 , no. 13809.

6 J. Buck, letter to Editor, Leicester Chronicle, 12 March 1853. J. Moore, Annual health report 1856, Leicester Corporation, 1857, p. 7; ibid., 1864, p. 6. J. Dare, Annual report Leicester Domestic Mission Society for 1864, Leicester, The Society, 1864, p. 15. J. W. Crane, Annual health report 1867, Leicester Corporation, 1868 , p. 8.

7 S. M. F. Fraser, 'The Borough Smallpox and Fever Hospital, Freake's Ground', [unpublished manuscript].

8 Fever Hospital Committee Minutes, 9 January and 10 April 1873. 


\section{Leicester and smallpox: the Leicester method}

\section{NOTIFICATION}

A hospital having been provided, cases were required. The value of notification of any particular disease was not appreciated. The nearest procedure to notification was a system devised from 1857 in Leicester where the Medical Officer of Health organized the Sanitary Inspectors (Inspectors of Nuisances) to make house-to-house enquiries in the locality of every smallpox case. This was primarily to ensure that all the children had been vaccinated as required by the law. 9

Once the Freake's Ground Hospital was opened and smallpox cases began to decline, the Council asked the Hospital Steward, Mr. Dalrymple, and the Sanitary Inspectors to persuade all smallpox cases to be admitted. After the epidemic the Council continued to encourage maximal use of the hospital for suitable cases. This was possible and partly successful because Mr. Dalrymple was also Manager of the Provident Dispensary and ideally situated to know of illness occurring in the town, and so was able to co-ordinate the inspectors' work. ${ }^{10}$

Despite these informal measures not all cases were notified, so in 1876 further to encourage notification the Sanitary Committee introduced a notification fee: two shillings and sixpence, to be paid on notification of any case of smallpox, scarlet fever, or erysipelas who would consent to hospital admission. ${ }^{11}$ It should be pointed out that patients could not be compulsorily admitted to hospital unless they had no fixed abode, or lodged in a room with another family.

\section{DR. W. JOHNSTON}

During the mid-1870s Leicester suffered as did other rapidly growing industrial Victorian towns, but had an especially high infant death rate, due mainly to "summer diarrhoea".12 Vaious individuals submitted reports and suggestions to improve the situation. ${ }^{13}$ In May 1877, the Corporation moved to combat the high rate of infectious epidemic diseases by appointing Dr. William Johnston as assistant to the ageing Medical Officer of Health, Dr. J. W. Crane. Johnston combined this post with that of Medical Officer to the Fever Hospital.14

Unfortunately little is known of Dr. Johnston's earlier career. He had been in medical practice in Leicester since late 1875 or early 1876.15 On his appointment as

9 J. Moore, Annual health report 1857, Leicester Corporation, 1858, pp. 7-8.

$10 \mathrm{Mr}$. Dalrymple was very influential in maximizing the use of the hospital; it was at his suggestion that the Medical Officer made annual reports. He admitted several smallpox cases in 1874, although Dr. Crane stated that he was unaware of any local cases during that year. Fever Hospital Committee Minutes, 12 December 1872. Sanitary Committee Minutes, October 1874, and 15 January and 21 May 1875.

11 Leicester Town Council Subcommittee Minutes, 6 December 1876.

12 Simmons, op. cit., note 2 above, pp. 6-16.

13 J. W. Crane, Annual health reports 1867 to 1879. J. Dare, Annual report Leicester Domestic Mission Society, 1847 onwards, especially 1851, 1852, and 1869. R. Weaver, Sanitary enquiry, [pamphlet], Leicester, 1871. J. St. T. Clarke, To the Urban Sanitary Authority of the Borough of Leicester, [an address], Leicester, 1872. W. E. Buck and G. C. Franklin, On the epidemic diarrhoea of 1875, [pamphlet], Leicester, 1876. J. Sloane, Report on infantile diarrhoea, Leicester, Spencer Bros. \& Russell, 1876. W. Johnston, The diarrhoea of Leicester, its cause and prevention, Leicester, Spencer Bros \& Russell, 1876. A. McC. Weir, Infantile mortality and summer diarrhoea, their causation and cure with reputation of the sewer gas and germ theory, Leicester, Batty, 1878.

14 Sanitary Committee Minutes, 21 and 23 March, and 18 May 1877.

15 William Johnston, M.D., M.Ch., R.U.I. 1870 Queen's University Belfast. Born 1845 Belfast - died 1900 Leicester. He was a frequent prize-winner as a student, and qualified with Honours and Gold Medal. 
Assistant Medical Officer of Health he unified several separate procedures which had developed independently in the town for dealing with epidemic infectious diseases: as Medical Officer of Health he liaised with the Sanitary Inspectors, had power to disinfect premises, and influence on the Town Council; as Medical Officer to the Freake's Ground Hospital he had immediate access to a means of isolating cases; he had recruited the matron to this hospital;16 as a Dispensary Medical Officer he had close contact with a large section of medical practice in the town.

Although primarily concerned with the high infant mortality, the diarrhoea epidemics, scarlet fever, and other general public health measures, Johnston immediately formulated a system for dealing with smallpox, and in his first report published in 1878 he described its first six months. In addition to procedures already in use, he insisted that all cases be notified and admitted to hospital, often by "gentle" persuasion. He also quarantined all contacts of a smallpox case on the same site. To ensure the effectiveness of this system, he recommended that the Council obtain powers of notification by a local Act of Parliament. ${ }^{17}$ In response, the Council secured compulsory notification by the Leicester Corporation Act of 1879.18 Johnston had meanwhile managed to continue unofficial notification of smallpox cases throughout 1878 and 1879 until the act came into force. The act was opposed by an influential section of the local medical profession, who felt it intruded into the privacy of doctorpatient confidentiality. This resistance appears to have been largely ignored, probably due to Alderman T. Windley, the Chairman of the Sanitary Committee, who was known to dislike doctors. ${ }^{19}$ It seems that no objections were forthcoming from any

He was in practice in England from 1872, and by 1875 he was Medical Officer to the Clay Cross Colliery Hospital. He married in December 1875 and moved to Leicester where he was elected a Medical Officer to the Provident Dispensary and later a Poor Law Medical Officer. (Details of undergraduate period: Secretary, The Queen's University of Belfast. Details from 1875: A family scrapbook of Dr. Johnston's great niece-inlaw Dr. Katherine Smith of Ashby de la Zouch; also Leicester Daily Post, 24 April 1877.)

16 Johnston appointed a new matron, Miss O'Sullivan, previously Night Superintendent at the Fever Hospital, London, within a month of his own appointment. Sanitary Committee minutes, 2 and 27 July 1877.

17 W. Johnston, Report on the principal zymotic diseases during 1877, Leicester Corporation, 1878, p. 11. "In any house where a smallpox case occurred I endeavoured to impress the inmates with the fact that the removal of all members of the family to the Hospital was the best course to adopt . . . .

"Altogether 22 unaffected cases were thus admitted into quarantine, and of those, three after admission sickened. The first case sickened in $\mathbf{4 8}$ hours, the second in $\mathbf{7 2}$ hours, whilst the third showed no symptom of the disease until the 12 th day . . . .

"The suppression of what might otherwise have proved a widespread epidemic attended with great fatality was entirely due to the early information received of the cases affected and the promptitude observed in their removal."

18 Leicester Corporation Act 1879 Sect. 8

19 This objection came primarily from the Leicester Medical Society who arranged special discussion meetings and elected a sub-committee to present their objections to the Town Council and Parliament. Only fifteen of the 50+ doctors listed in the town were present at the Society's meetings, and it is not known how many local doctors signed the circular presented to the Town Council, although the conviction of some of the signatories must be in doubt, as Dr. J. W. Crane, the Medical Officer of Health signed it. At the subsequent Sanitary Committee meeting he stated that if this was so he would erase his name. Dr. Johnston was present at some of the Society's meetings, but his comments are not recorded.

Alderman Windley's opinion of the profession was made known to the Society by Henry Lankester, a general practitioner who was also a councillor. The Society's objections cost them $£ 160$ in legal fees alone. Leicester Medical Society Minute Book V, 27 December 1878, 31 January and 7 October 1879, and 13 January 1882. Sanitary Committee Minutes, 10 January 1879. C. R. Crossley, 'Compulsory registration of infectious disease', Lancet, 1879, i: 826. 


\section{Leicester and smallpox: the Leicester method}

other groups or individuals. ${ }^{20}$

Johnston succeeded to the Medical Officer's position in 1880 on Dr. Crane's retirement. He continued in the post until 1885, when, due to the pressure of his growing private practice, he resigned.21

\section{DRS. TOMKINS AND PRIESTLEY}

Henry Tomkins succeeded Johnston as Medical Officer of Health; his was the first full-time appointment, and the post was now combined with those of Medical Officer to the Fever Hospital, Public Analyst, and Police Surgeon. ${ }^{22}$ Tomkins did not alter his predecessor's system of dealing with smallpox. However, it was during his term of office that the use of vaccination became a controversial issue. Johnston in his annual reports had made no specific mention of vaccinating staff or quarantinees, although he was known to support vaccination. It is recorded of Johnston that "only in very rare instances was it [vaccination] done with the consent of the individuals by the ex-officer of health Dr. Johnston, and that is so long since that he does not remember it."23 Leicester had become the anti-compulsory vaccinationist capital of the country by 1885, and in 1886 a Lancet correspondent visited the town. He inspected the Fever Hospital and interviewed Alderman Windley and Drs. Johnston and Tomkins. Although his report is typical of the confused thinking about vaccination and smallpox current at that time, he described the Leicester system as originally devised by Johnston and continued by Tomkins. He emphasized that the latter ensured that he and his immediate staff were adequately vaccinated or revaccinated, and also offered vaccination to the close contacts of the cases. ${ }^{24}$ Few cases of smallpox occurred in Leicester after 1885 (Table I).

In 1892 a new Medical Officer of Health, Dr. Joseph Priestley, was appointed, Dr. Tomkins having died in office. ${ }^{25}$ Within a few months of this appointment, the 1892-94 smallpox epidemic commenced. It was the first major test of Johnston's original system.

The danger of having smallpox cases on the same premises as other diseases was highlighted. Dr. Priestley misdiagnosed a sick child in the quarantine wards as having chickenpox. The child was transferred to a room in the scarlet fever ward which was full at the time. It was not until later that the correct diagnosis of smallpox was made. The whole hospital was by this time grossly overcrowded with scarlet fever cases and an ever-increasing number of smallpox patients and quarantinees. The hospital was cleared of all cases during 1893 except smallpox. Some of the children, now incubating smallpox, were amongst those discharged, to be readmitted later when their smallpox

\footnotetext{
20 A search of the contemporary local newspapers has not revealed any public or editorial comments against the Notification Act.

21 W. Johnston, Annual report on zymotic diseases and infant mortality, Leicester Corporation, 1877 and 1878. W. Johnston, Annual health reports, 1879-1884. Sanitary Committee Minutes, 15 and 22 May 1885, for details of his resignation.

22 Ibid., 1 and 29 June, and 10 July 1885 , at salary of $£ 500$ per annum.

23 J. T. Biggs, Leicester: sanitation versus vaccination, London, National Anti-Vaccination League, [1912], pp. 369 and 474.

24 'The Leicester anti-vaccinationists', Lancet, 1886, i: 1036. 'Leicester protected by vaccination', ibid., p. 1086. [Special Commissioner], 'Leicester and its immunity from smallpox', ibid., pp. 1090-1091.

25 Sanitary Committee Minutes, 1 April and 3 June 1892.
} 
Stuart M. F. Fraser

TABLE I

SMALLPOX IN LEICESTER, 1852-1933

\begin{tabular}{|c|c|c|c|}
\hline & $\begin{array}{l}\text { Total cases in } \\
\text { Borough including } \\
\text { Fever Hospital }\end{array}$ & $\begin{array}{c}\text { Numbers } \\
\text { quarantined }\end{array}$ & $\begin{array}{l}\text { Total deaths, } \\
\text { including Fever } \\
\text { Hospital }\end{array}$ \\
\hline 1852 & & & 52 \\
\hline 1853 & & & 11 \\
\hline 1854 & & & - \\
\hline 1855 & & & - \\
\hline 1856 & $16+$ & & 1 \\
\hline 1857 & $?$ & & 17 \\
\hline 1858 & $?$ & 0 & 53 \\
\hline 1859 & $?$ & 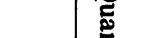 & 3 \\
\hline 1860 & $2+$ & 气ै & 2 \\
\hline 1861 & $?$ & 롤. & 1 \\
\hline 1862 & $?$ & อ & - \\
\hline 1863 & a number in several houses & 요 & 5 \\
\hline 1864 & $?$ & $\vec{E}$ & 104 \\
\hline 1865 & $?$ & 8 & 10 \\
\hline 1866 & $?$ & $\Xi$ & 3 \\
\hline 1867 & $?$ & 总. & 2 \\
\hline 1868 & a few cases & $=$ & 1 \\
\hline 1869 & $2-3$ cases & $\underset{1}{\infty}$ & - \\
\hline 1870 & $?$ & & - \\
\hline 1871 & estimated 3,000 cases & & 12 \\
\hline 1872 & estimated 3,000 cases & & 346 \\
\hline 1873 & $?$ & & 2 \\
\hline 1874 & 'several' & & - \\
\hline 1875 & 3 at least & & 1 \\
\hline 1876 & - & & - \\
\hline 1877 & 12 & 22 & 6 \\
\hline 1878 & 8 & 21 & 1 \\
\hline 1879 & - & - & - \\
\hline 1880 & 1 & - & - \\
\hline 1881 & 6 & 3 & - 2 \\
\hline 1882 & 29 & 33 & 5 \\
\hline 1883 & 12 & 26 & 3 \\
\hline 1884 & 6 & 13 & - \\
\hline 1885 & 8 & 10 & - \\
\hline 1886 & 1 & 2 & - \\
\hline 1887 & 10 & 14 & - \\
\hline 1888 & 22 & 39 & - \\
\hline 1889 & - & - & - \\
\hline 1890 & - & - & - \\
\hline 1891 & - & - & - \\
\hline 1892 & 38 & 283 & 6 \\
\hline 1893 & 320 & $1,271^{*}$ & 15 \\
\hline 1894 & 8 & 55 & — \\
\hline 1895 & 4 & - & - \\
\hline 1896 & - & - & - \\
\hline 1897 & - & - & - \\
\hline 1898 & - & - & - \\
\hline 1899 & - & - & - \\
\hline 1900 & - & - & - \\
\hline 1901 & 4 & 5 & - \\
\hline 1902 & 18 & 156 & 5 \\
\hline 1903 & 406 & 1,919 & 21 \\
\hline 1904 & 307 & 823 & 4 \\
\hline 1905 & 5 & 62 & - \\
\hline
\end{tabular}


Leicester and smallpox: the Leicester method

TABLE I CONTINUED

\begin{tabular}{|c|c|c|c|}
\hline & $\begin{array}{c}\text { Total cases in } \\
\text { Borough including } \\
\text { Fever Hospital } \\
\end{array}$ & $\begin{array}{l}\text { Numbers } \\
\text { quarantined }\end{array}$ & $\begin{array}{c}\text { Total deaths, } \\
\text { including Fever } \\
\text { Hospital }\end{array}$ \\
\hline $\begin{array}{l}1906 \\
1907\end{array}$ & 1 & 8 & - \\
\hline $\begin{array}{l}1923 \\
1924 \\
1925 \\
1926 \\
1927 \\
1928 \\
1929 \\
1930 \\
1931 \\
1932 \\
1933\end{array}$ & $\begin{array}{r}- \\
5 \\
72 \\
-7 \\
90 \\
320 \\
1,192 \\
1,353 \\
183 \\
-\end{array}$ & $\begin{array}{l}\text { most cases are of } \\
\text { variola minor. } \\
\text { Quarantine not so strict } \\
\text { mostly at own homes - no } \\
\text { record of numbers in } \\
\text { M.O.H. reports }\end{array}$ & $\begin{array}{l}1 \\
1\end{array}$ \\
\hline
\end{tabular}

* From 1893 quarantine often done in the person's own home - previous figures are the numbers quarantined on the hospital premises - after this date numbers under quarantine control.

Source of figures: Biggs, op. cit., footnote 23; Annual health reports 1856 to 1933 used to check details and add details of 1923-33.

manifested itself. Quarantine accommodation quickly became inadequate, so the Medical Officer isolated contacts in their own homes or lodgings, under regular supervision from the Sanitary Inspectors. At one time 104 people were kept under quarantine in one common lodging-house.

In addition, the site of the hospital was becoming unsuitable. It had originally been built clear of residential areas, but by the 1890 s it was closer to the rapidly expanding town. Controls of the hospital staff, laundry, and the flow of visitors were inadequate and probably allowed dissemination of smallpox into the town.

However, there were some hopeful signs, for only 358 cases occurred in the town (1891 population census, 174,624$)$ - this was a low number for an urban area by then "unprotected" by infant vaccination. Only twenty-one of these cases proved fatal (5.8 per cent), again a low mortality for smallpox. It would therefore appear that the disease was kept under control at all times and there was certainly never any panic, or disruption of trade in the town. Inhabitants seemed confident that the authorities could contain the disease (compared with Sheffield in 1887 and Montreal in 188826). The hospital also managed to accommodate all the cases that occurred, although only at the expense of scarlet fever cases. (At that time it was considered that isolation would control scarlet fever - 2308 cases of which were notified in 1893 alone.) I feel that the fact that all smallpox cases received professional nursing care in a hospital may explain in some measure the low overall mortality.

There were also problems more peculiar to Leicester, due to the residents' attitude to compulsory infant vaccination (see below). The Medical Officer of Health clashed with the Sanitary Committee over the vaccination and revaccination of hospital staff and quarantinees. Dr. Tomkins had vaccinated a few contacts, and Dr. Priestley wished to

26 Sheffield epidemic, Royal Commission, op. cit., note 1 above, pp. 273-276. Henry Tomkins, 'Smallpox in Montreal: the story of an epidemic', Br. med. J., 1888, i: 1019-1020. 
vaccinate more extensively. He managed to vaccinate twenty-seven people in 1892; and in 1893 only 123 of 1544 quarantined in all. He was then expressly forbidden by the Sanitary Committee to pursue vaccination. Even some of the hospital staff refused vaccination, including the matron; five of them subsequently developed smallpox, and one died.27

The Local Government Board closely observed Leicester's management of the epidemic by sending Dr. Sidney Coupland there. ${ }^{28}$ The epidemic waned and the years 1894-1901 were quiet ones as far as smallpox was concerned (see Table I).

\section{DR. C. K. MILLARD}

In 1901 Dr. C. K. Millard, who had considerable experience relating to smallpox, was appointed Medical Officer of Health. ${ }^{29}$ Whilst in Leicester he dealt with the last two smallpox epidemics of 1902-04 and 1928-31. Dr. Millard held the conventional views on the use and value of vaccination. However, he continued to use the Leicester Method pioneered by his predecessors. Locally feelings against vaccination had mellowed, probably helped by the 1898 Act which allowed conscientious objection if supported by a magistrate. Millard was able to ensure that all his staff were recenlty and thoroughly vaccinated, although the Town Council made a point of emphasizing the freedom of choice in the matter by displaying a notice in the hospital. ${ }^{30}$ It should be noted that Dr. Millard's views on the management of smallpox were modified by his Leicester experience, as he in turn was able to modify the Leicester Method by adding

27 The 1892-94 smallpox epidemic is described in detail in the following: J. Priestley, Annual health report, 1892, pp. 85-120; 1893, pp. 87-203; 1894.

28 The Royal Commission considering the Vaccination Acts was sitting at this time. The fact that 66 per cent of the cases that occurred in Leicester were in children under ten was used to support compulsory infant vaccination. In fact infant vaccination had merely altered the age distribution of the cases occurring during the epidemic, and the fact that few cases occurred overall in Leicester has been overlooked.

$\begin{array}{lccc} & \begin{array}{c}\text { smallpox } \\ \text { cases per } \\ 10,000 \text { pop. }\end{array} & \begin{array}{c}\text { total no. of } \\ \text { cases } \\ \text { occurring }\end{array} & \begin{array}{c}\% \text { of cases } \\ \text { occurring in }\end{array} \\ \text { London 1892-3 } & 5.5 & 2353 & 0-10 \text { yr. olds } \\ \text { Leicester 1892-3 } & 20.5 & 357 & 36.8 \\ \text { Warrington 1892 } & 125.3 & 661 & 66.6 \\ \text { Sheffield 1887-8 } & 144.2 & 4677 & 22.5 \\ \text { Dewsbury 1891-2 } & 339.0 & 1012 & 25.6 \\ \text { Gloucester 1895-6 } & 501.7 & 1979 & 51.8\end{array}$

Warrington and Sheffield represented well-vaccinated towns.

London represented a relatively well-vaccinated town.

Dewsbury, Gloucester, and Leicester represented poorly-vaccinated towns.

(H. Paul, The control of disease, Edinburgh and London, Livingstone, 1964, p. 209. Census of England and Wales, 1891, London, H.M.S.O., 1893, vol. 2: Registration areas and sanitary districts.)

29 Charles Killick Millard, M.D., D.Sc. 1870-1951. Leicester Medical Officer of Health 1901-1935. He was resident Medical Officer to the Birmingham Fever and Smallpox Hospital during the epidemic of 1892 94, and subsequently studied smallpox for both his M.D. and D.Sc. He accepted the Leicester appointment to further his career, in response to the challenge of Leicester's attitude to smallpox and vaccination. His knowledge of the disease also greatly commended him to the Town Council. C. K. Millard, Smallpox and vaccination: my confession of faith, reprinted from The Vaccination Inquirer, May-June, July-August, and September-October 1950, [pamphlet]. (Maurice L. Millard, M.B., Ch.B., C. K. Millard's son, personal communication, 1979.)

30 Sanitary Committee Minutes, 24 June 1902. Notice displayed in New Isolation Hospital, Gilroes, "No member of Hospital or Sanitary staff need be revaccinated unless they wish it." 


\section{Leicester and smallpox: the Leicester method}

selective vaccination. 31

From 1900 onwards the method was no longer considered such an oddity, as most health authorities tried to carry out a similar system, within the limits of their resources. However, there persisted in Leicester an emphasis first on notification, isolation, quarantine, and disinfection, and second on vaccination. Official belief placed prime emphasis on vaccination and revaccination, other procedures being of secondary importance. ${ }^{32}$ It was not until 1899 that national universal notification of smallpox came into force. This was primarily due to the experience of Leicester and other towns with notification acts, presented in evidence to the Royal Commission on the Vaccination Acts 1889-1897.33

Dr. Millard wrote and spoke extensively on smallpox and vaccination. He emphasized the protection given by recent vaccination, and argued that the Leicester Method was of value in protecting a community from an epidemic. He stressed the hazard to society of a person vaccinated in infancy subsequently developing "modified smallpox". This person's illness was (and still would be) difficult to identify and capable of spreading true smallpox before diagnosis. Following his conversion to Leicester and its ways, he advocated the Leicester Method combined with his use of selective vaccination. He also campaigned for repeal of the Infant Vaccination Acts from 1912-1914 onwards.

\section{DISCUSSION}

Smallpox was a major cause of death and morbidity in England in the eighteenth century. From the late eighteenth century onwards it began to decline, although there were two large nationwide epidemics in 1838 and 1871. From 1873 smallpox deaths declined further except during the two small epidemics of 1892 and 1901. It has been surmised by Creighton that smallpox first left the richer classes, then the rural areas, and finally the urban areas. The epidemics of the latter half of the nineteenth century were primarily a problem of the towns, London presenting the greatest source of the disease. ${ }^{34}$

It has been argued that the introduction of inoculation, especially the safer Suttonian method, began the decline. 35 The gradual introduction of Jennerian vaccination coincided with or caused a further decline.

In the mid-nineteenth century medical opinion was unswervingly in support of the belief that vaccination was an essentially harmless procedure which if carried out correctly gave lifelong protection. The Victorian government tried to enforce this belief with the various Vaccination Acts, the first of 1840 instigated in reaction to the severe

31 Millard (1950), op. cit., note 29 above, and also his book, The vaccination question in the light of modern experience, London, Lewis, 1914, a work neglected probably due to its publication date which coincided with the outbreak of World War I.

32 William Osler, Principles and practice of medicine, New York and London, Appleton, 1916, p. 324.

33 Royal Commission, op. cit., note 1 above, pp. 269, and 480-481.

34 Charles Creighton, $A$ history of epidemics in Britain, 2 vols., [2nd ed., London, 1894], reprinted London, Frank Cass, 1965, vol 2, pp. 434-631.

35 See P. Razzell, The conquest of smallpox, Firle, Sussex, Caliban Books, 1977, for the suggested value of the introduction of inoculation. 
national epidemic of $1837-40.36$

However, there were measures other than vaccination which had begun to be developed prior to Jenner, but which had been forgotten in the enthusiasm for vaccination. The most important of these was hospital isolation. Several plans had been projected: 1763 Rest of Lyons; 1770 Rhode Island, U.S.A.; 1781 the use of pesthouses; 1784 Haygarth of Chester; and in the 1790s Willan and Ringe. Few of these plans had been followed, only Haygarth's and the use of Rhode Island. 37

From the 1840s onwards Edwin Chadwick and his supporters had advocated general sanitary improvements, and following the Public Health Acts of 1848 and 1875 these ideas were gradually taken up. A combination of the above concepts was occasionally used to combat some infectious diseases. 38

Seaton in 1869 described how to deal with smallpox in a community, but this would appear to be textbook advice from an ardent provaccinationist, and it is not known to what extent it was acted upon. 39

Leicester stands as an example, probably the first, where measures other than total reliance on vaccination were introduced successfully to eradicate the disease from a community. The town had been early in providing some form of hospital accommodation. Although designed to deal with a temporary contingency, the Borough Fever and Smallpox Hospital was used for twenty-two years. Unlike the experience in other localities, once opened, this hospital was never closed down. Although too large for everyday use, it could absorb the increased numbers of an epidemic, for which purpose it had originally been built.

A system of immediate notification, isolation, and quarantine of contacts is one which has proved particularly effective in containing and limiting smallpox. ${ }^{40}$ As mentioned above, these measures had been used against other infectious diseases with varying effect. Plague had been contained by using quarantine, ${ }^{41}$ but Huddersfield's experiences against scarlet fever in 1876 had met with little success. ${ }^{38}$

36 R. J. Lambert, 'A Victorian national health service, state vaccination 1885-1871', Hist. J., 1962, 5: 1-18.

37 Royal Commission, op cit., note 1 above, pp. 255-258.

38 The 1840 s saw the beginning of local and national government involvement in preventative public health measures. Bolton and Huddersfield in 1876 introduced legislation to enforce notification of fever cases, in association with other current public health measures. Huddersfield particularly enacted local legislation to isolate scarlet fever cases in their homes or the local hospital, restricted the contacts' movements, prevented school attendance, and carried out general disinfection. They were unsuccessful, and did not use their facilities against smallpox. Details of these public health measures are incomplete as there are no annual Medical Officer of Health reports prior to 1890 , and no scarlet fever statistics prior to 1881 . C. Singer and E. A. Underwood, A short history of medicine, 2nd ed., Oxford University Press, 1962, pp. 217 224. Reports of the Local Government Board: 7 th report 1877-1878, London, H.M.S.O., 1878, p. CXVI; ibid., 10 th report supplement $1880-81$, p. 131. The Huddersfield Waterworks and Improvement Act 1876, Section 64 (Hospitals and infectious diseases), shows the theoretical working of their method. (Personal communication from Chief Librarian and Curator, Kirklees Metropolitan Council.)

39 E. C. Seaton, A handbook of vaccination, London, Macmillan, 1868, pp. 283-284.

40 An unvaccinated person who develops smallpox is thought not to be infectious until the vesicles appear and break out on the mucosa of the respiratory tract. This phase coincides with a high fever, headache, and backache, so the person partly isolates himself from the community and is a danger only to his immediate family. A. B. Christie, Infectious diseases epidemiology and clinical practice, Edinburgh and London, Livingstone, 1974, p. 213.

41 Singer and Underwood, op. cit., note 38 above, p. 198. 


\section{Leicester and smallpox: the Leicester method}

However, such a system required an active and diligent health staff supported by an enlightened Council. Leicester Town Council's Sanitary Committee was such a body, prepared to pursue health measures vigorously within their financial constraints. They had taken rapid action on Dr. Johnston's advice to obtain a notification bill, despite the local medical opposition. The number of health staff was slowly increased during the 1870 s and 1880 s, the loyalty and hard work of key health officials being of paramount importance. Dr. Johnston laid the foundations by developing the system, which was ably continued by his six successors and their locums from 1877 to 1902 . Modifications were attempted and carried out as dictated by the current situation or by advances in medical knowledge. Each Medical Officer of Health, however, retained his independence and individuality, as can be witnessed by occasional forthright comments included in the Annual health reports and in committee. 42

Important continuity was provided by Alderman T. Windley, who was chairman of the Sanitary Committee from 1876 to 1923, and by Francis Braley, who was appointed a Sanitary Inspector in 1875 . He became Chief Inspector in 1890, and continued in office until 1922, carrying out or organzing a large part of the method.43

Despite their earlier misgivings, the doctors aided with prompt notification. They always gave good support to the Medical Officers, but if they appeared tardy in notification the Sanitary Committee did not hesitate to prosecute. 44 However, diagnosis has always presented problems, expecially in cases of modified smallpox. Dr. Priestley made this error in 1893, and the danger of an adult, vaccinated in infancy, developing modified smallpox prompted Dr. Millard to advocate the repeal of the Vaccination Acts. 45

Quarantine control of contacts appeared to have been employed for the first time in Leicester, and I am not aware of its use by any other town or authority, particularly in association with the other procedures against smallpox. ${ }^{46}$

Leicester had a poor reputation as regards health before 1870, the New Reformed Corporation being limited by the financial excesses of the Old Corporation. Measures such as fresh piped water, sewerage systems, and the appointment of health officials were taken, but they were never adequate to deal with the rapidly expanding town. After 1870 increasing local and government legislation, interest, money, and personnel improved the situation, which was demonstrated after 1900 in a decreasing infant mortality rate (Graph I). These developments came at the same time as the introduction of specific measures against smallpox.

\section{THE ANTI-VACCINATIONISTS}

The influences of the Vaccination Acts and the anticompulsory vaccination movement are the next factors I shall consider, for by the mid-1880s Leicester had

42 M. Elliott, Victorian Leicester, London, Phillimore, 1979, especially chapters 2-5. Also contemporary Annual health reports, Town directories, and Town accounts.

43 T. Windley, Reviews of the works of the Sanitary Committee 1873-1917, [pamphlet], Leicester, 1918, shows the involvement of Alderman Windley in the town's health. Millard (1914), op. cit., note 31 above, p. 129, emphasizes Braley's long service as an important and useful factor. Braley is listed as Chief Sanitary Inspector until 1922 in the contemporary Town directory.

44 Sanitary Committee Minutes, 12 October and 21 December 1883, 16 June 1893.

45 C. K. Millard, 'Smallpox and vaccination', Lancet, 1924, i: 301.

46 Fraser Brockington, The theory and practice of public health, Oxford University Press, 1975, p. 143. 


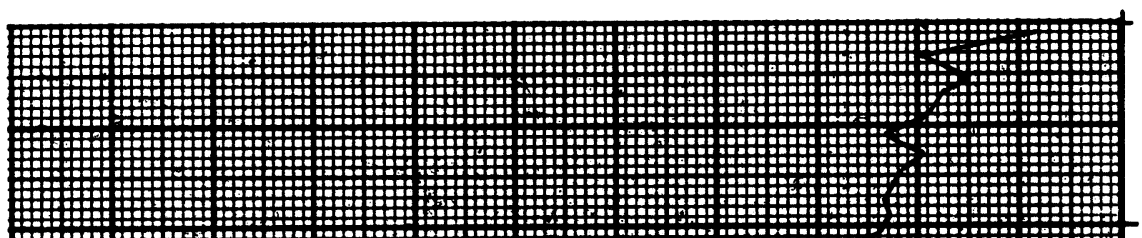

윰

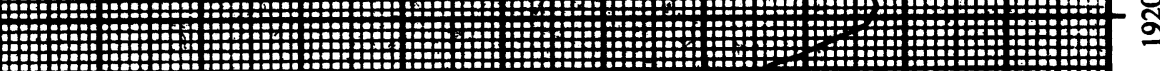

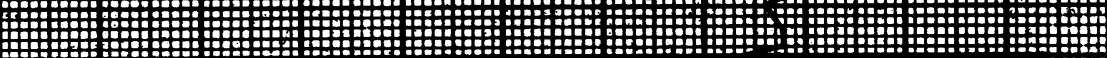
张  鹿张 约 约

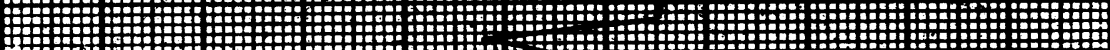

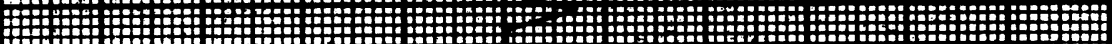
( 张 地

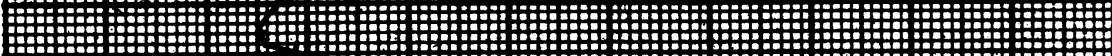
鹿鹿地 鹿张 鹿张 鹿张 地

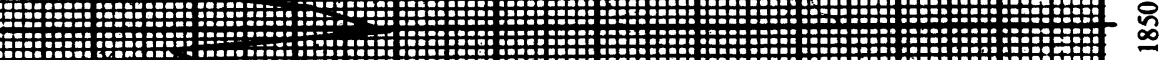
约 鹿张 (ֻ 地 鹿地

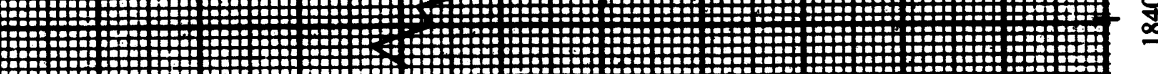




\section{Leicester and smallpox: the Leicester method}

become something of a curiosity due to its attitude to smallpox, vaccination, and vaccination legislation.

Vaccination legislation in England and Wales had begun in 1840 and culminated in the strict 1871 Act. Thus by 1871 a universal compulsory system of infant vaccination, by public vaccinators, and organized locally by Boards of Guardians, had been set up. Vaccination officers were compulsorily employed to prosecute parents who refused to have their children vaccinated, if necessary repeatedly. ${ }^{47}$ It was not appreciated until the late nineteenth century that revaccination was required for full benefit, and that the arm-to-arm technique used until 1898 had hazards. ${ }^{48}$ This is not to deny that vaccination did confer some degree of protection against smallpox, but unfortunately the medical benefits had become involved with the law and with government attempts at public health measures of disease control.

The movement against the Vaccination Acts has been fully described in a national context by Roy MacLeod,49 who emphasizes particularly the unique position of Leicester because of its system. The anti-vaccinationist movement in Leicester has also been mentioned in local histories, but the impression has been given that it started in 1869 , and progressively gained impetus so that by 1885 the town had become the nation's leading anti-vaccinationist centre. ${ }^{50}$ The latter statement is correct; the former gives a false impression of the development of the "cause".

A detailed examination of the facts shows what actually happened in Leicester. Contemporary sources list annual numbers of births and infant deaths (see above), the number successfully vaccinated each year (Graph II), the numbers avoiding vaccination (Table II), and the numbers summonsed and subsequently imprisoned for non-compliance with the Vaccination Acts (Table III). It must be remembered that the anti-vaccinationists consisted of two groups united in one aim: those against vaccination in all its forms, who were mainly parents intimately involved in the procedure; and second, those against the political implications of a compulsory parliamentary act. From an examination of the social position of the people involved in the Leicester movement, it would seem that the ardent anti-vaccinationists were artisan working-class parents, whilst the middle-class members (hosiers, excouncillors, ex-mayors, magistrates, and guardians) were primarily against the compulsion of the acts. ${ }^{51}$

These facts indicate that, although there were always a few parents who would not comply with the law, until 1878 Leicester's population showed a satisfactory percentage of vaccinations in comparison with other Unions in England and Wales. From 1878 onwards the numbers of infants avoiding vaccination drew official comment and rebuke, but the total numbers vaccinated remained sixty per cent or more until 1883. It was from this latter date that the numbers vaccinated dropped

47 Lambert, op. cit., note 36 above, pp. 2-12.

48 Sir Arthur S. MacNalty, 'The prevention of smallpox: from Edward Jenner to Monkton Copeman', Med. Hist. , 1968, 12: 1-18.

49 MacLeod, op. cit., note 1 above.

50 McKinley and Smith, op. cit., note 2 above, p. 280. D.-L. Ross, 'Leicester and the Anti-Vaccination Movement 1853-1889', Trans. Leic. Arch. Hist. Soc., 1968, 43: 35.

51 Biggs, op. cit., note 23 above, pp. 155-170, lists Leicester residents who gave evidence to the Royal Commission in 1891, and their reasons. Their occupations compared with contemporary Town directories. 
Stuart M. F. Fraser

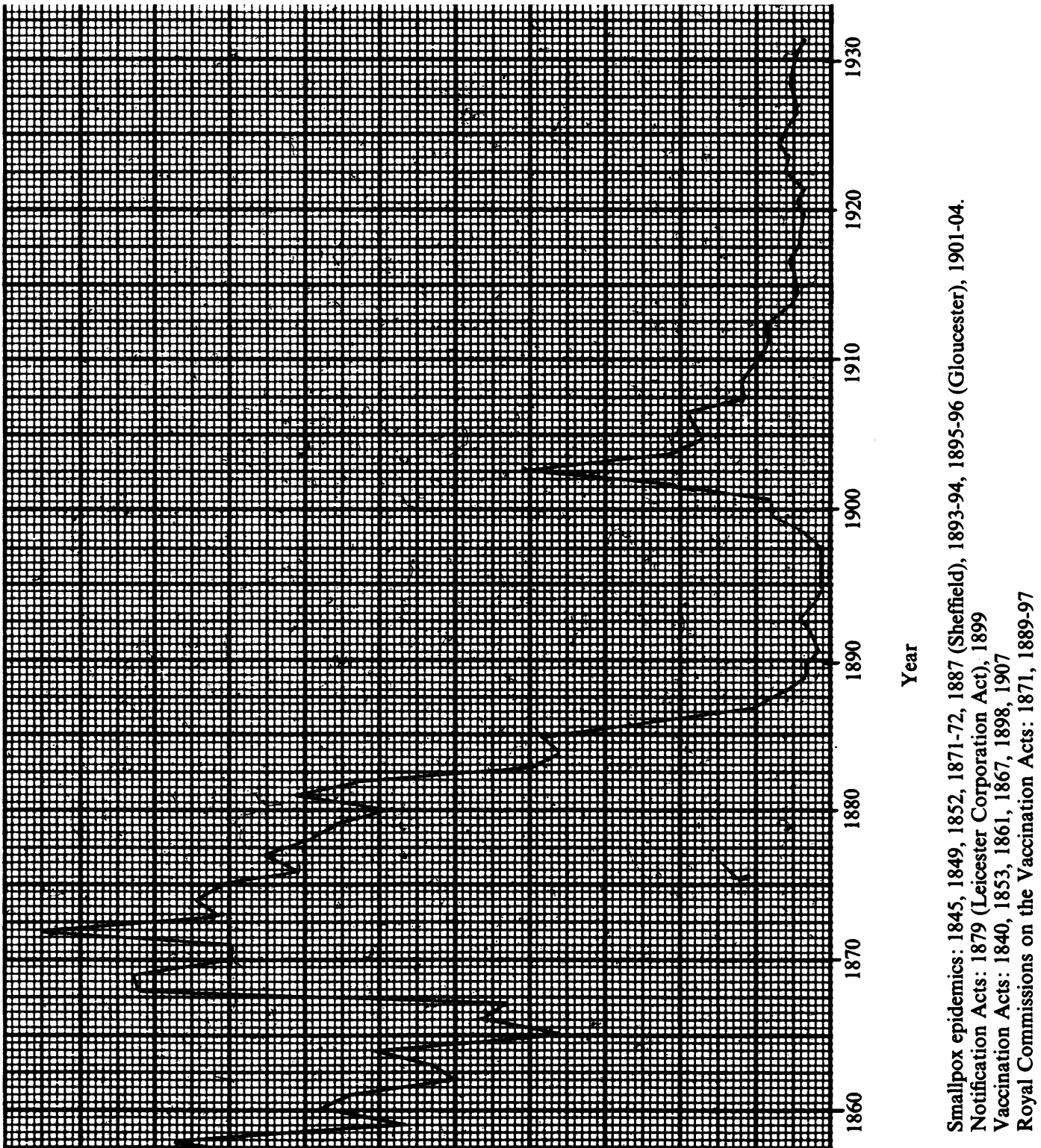

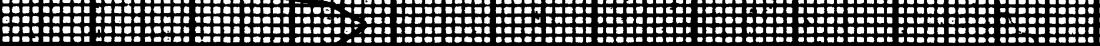
鹿

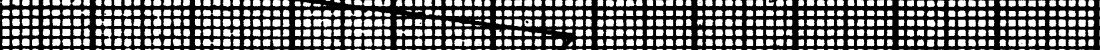

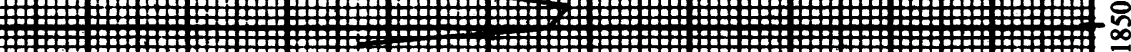
张

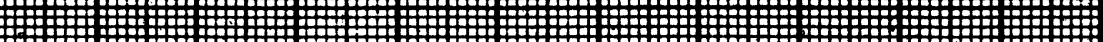

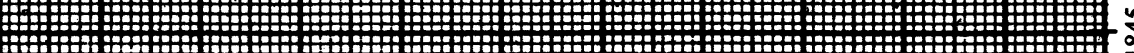

屁地 .

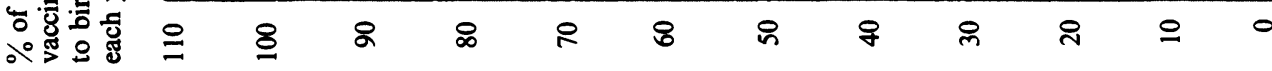




\section{Leicester and smallpox: the Leicester method}

TABLE II

PERCENTAGE OF BIRTHS "UNACCOUNTED FOR" BY VACCINATION"

$\begin{array}{cccc} & \text { Metropolis } & \text { Provinces only } & \text { Leicester Union } \\ 1875 & 9.3 & 3.8 & 4 \\ 1876 & 6.5 & 4.0 & 8.5 \\ 1877 & 7.1 & 4.1 & 7.3 \\ 1878 & 7.1 & 4.3 & 16.8^{*} \\ 1879 & 7.8 & 4.5 & 18.8 \\ 1880 & 7.0 & 4.5 & 21.2 \\ 1881 & 5.7 & 4.3 & 22.8 \\ 1882 & 6.6 & 4.5 & 30.2 \\ 1883 & 6.5 & 4.9 & 43.7 \\ 1884 & 6.8 & 5.3 & 47.9\end{array}$

"Unaccounted for" means all those births (i) not vaccinated; (ii) insusceptible to vaccination; (iii) who have had smallpox; (iv) who died unvaccinated; (v) and those whose vaccination has been postponed by medical certificate.

* The numbers unaccounted for by medical certificates are usually $<1 \%$, however in 1878 were $2.2 \%$ in Leicester.

Source of figures: Local Government Board annual report, from 1882 onwards figures contained in the supplement of the Medical Officer's report. Figures usually three years out of date by the time of publication; e.g., L.G.B. Report M.O. Suppl. 1886 gives 1883 figures.

TABLE III PROSECUTIONS AND IMPRISONINGS. LEICESTER.

\begin{tabular}{|c|c|c|}
\hline 1869 & Prosecuted & $\begin{array}{c}\text { Imprisoned } \\
3\end{array}$ \\
\hline 1870 & & - \\
\hline $\begin{array}{l}1871 \\
187 ?\end{array}$ & average of & 4 \\
\hline 1872 & 140 per & 4 \\
\hline 1873 & annum & - \\
\hline 1874 & & - \\
\hline 1875 & & 1 \\
\hline 1876 & $t$ & 9 \\
\hline 1877 & & 4 \\
\hline 1878 & & 2 \\
\hline 1879 & & 3 \\
\hline 1880 & & - \\
\hline 1881 & 1154 & - \\
\hline 1882 & 918 & 6 \\
\hline 1883 & 996 & $21 \ddagger$ \\
\hline 1884 & 1138 & 17 \\
\hline $\left.\begin{array}{l}1885 \\
1886\end{array}\right\}$ & 140 & \\
\hline 1887 & & \\
\hline
\end{tabular}

† It is known that 137 parents were summonsed this year, see Weir, op. cit., footnote 54, p. 9.

¥More were prosecuted.

Source of table: Biggs, op. cit., footnote 23, pp. 82, 90, 96, and 102-105.

markedly, never to recover. The numbers of parents summonsed and prepared to be imprisoned also support this view. Therefore I would suggest that Leicester was a lawabiding town until 1878, from 1878-1883 factors were influencing parents as to whether they should allow their children to be vaccinated, and from 1883 onwards the majority of parents defied the law. What were these influences? They were complex and interwoven; some have been mentioned above, but further important ones are as follows.

Generally there was a fluctuation in the degree of compliance with the vaccination acts. This was due to the absence or presence of smallpox epidemics and the current vaccination legislation. Newer and stricter acts were brought into force primarily 


\section{Stuart M. F. Fraser}

because of the decline in take-up of vaccination. As a result, numbers vaccinated increased, only to decline again as memories faded. These effects were reflected in the numbers vaccinated in Leicester, but there were other influential local factors.

Following the 1867 Vaccination Act, an Anti-Compulsory Vaccination League was established in London; this had a few provincial branches and Leicester was one of them. The original Leicester anti-vaccinationists held their first meeting in 1869 and less than twenty people attended. They would appear to have been a small number of mainly working-class parents who for some personal or religious conviction believed vaccination to be useless, harmful, or even evil. 52 During this early period the town was well vaccinated, but opposition was noted in the Medical Officer's annual reports of 1868,1869 , and 1870 .

However, as the years continued more parents heard of, saw, or experienced a growing list of complications attributed to vaccination. The 1871-72 smallpox epidemic gave a vivid example to the townspeople, in that although they had complied with the law some 3,000 cases occurred and of these $358 \mathrm{died}$, some of them vaccinated according to the law. 53 For the moment the numbers vaccinated continued at an acceptable level.

The exact numbers of parents prosecuted each year are not known, but from 1869 to 1880 an average of 150 persons were summonsed, a few even suffering imprisonment. A few prosecutions were attempted and dismissed in 1868, but in 1869 three parents were imprisoned. 1876 saw a reactivation of the cause and the local league was refounded as a branch of the Rev. W. Hume Rothery's National Anti-Compulsory Vaccination League (NACVL). He advocated "martyr tactics", and nine parents were imprisoned that year - an abnormally high number. It was not until 1880 when large numbers of parents refused to comply with the acts that the movement became a major influence in politics. ${ }^{54}$ Often the anti-vaccinationists gained sympathy from the harsh sentences and fines imposed by the magistrates. ${ }^{55}$ By 1885 nearly 3,000 parents were awaiting prosecution, a fact which stimulated the NACVL to mobilize a large demonstration in the town on 23 March 1885. This revitalized the whole movement nationally, and from this date Leicester became the anti-vaccinationists' capital.

From 1880 to 1882 the Vaccination Acts became an important local issue in municipal elections, although the Town Council itself had nothing to do with enforcing the acts. From 1882 a majority of the Corporation were anti-vaccinationists. The

52 Ibid., p. 79.

53 J. W. Crane, Annual health report for 1872, p. 7. Town Council Minutes, 13 August 1872 . Summary of the 219 in-patients who had been in the Freake's Ground Hospital to that date:

All cases of smallpox: 165 vaccinated $\quad-3$ died

10 unknown $\quad-2$ died 44 unvaccinated $\quad-19$ died.

54 All studies have to use Biggs' book (op. cit., note 23 above) as a source for facts concerning the antivaccination movement in Leicester. It must be remembered that it was written by a fanatic to the cause, and published forty-three years after the beginning of the movement. Biggs states that the movement began in 1869, yet the Leicester Daily Post, 26 February 1876, reports the first annual general meeting of the N.A.C.V.L. Leicester Branch. The 1878 annual general meeting could not obtain a quorum, Leicester Weekly Post, 16 March 1878. In 1876, a particularly bitter year, 137 persons were known to have been prosecuted and nine imprisoned. A. McC. Weir, Vaccination reform, [pamphlet], Leicester, J. \& T. Spencer, [c. 1878], p. 9. The Leicester Poor Law Union Minute Books do not list the numbers prosecuted each year.

55 It is noticeable that a parent found guilty in the Borough Court was fined ten shillings or seven days' imprisonment, similar cases were fined one shilling with $1 s$. $6 \mathrm{~d}$. costs in the County Court. Leicester Weekly Post, 16 March 1878, court reports. Leicester Daily Post, 22 January and 23 September 1876. 


\section{Leicester and smallpox: the Leicester method}

Board of Guardians, however, continued to enforce the acts until 1886, although occasionally by a marginal majority. 56 After 1886 the Guardians were opposed to vaccination, much harm having been done to the official view by the earlier persistent prosecutions. By 1899 the Guardians were so against vaccination that they refused to appoint a new Vaccination Officer until forced to do so by the government. This officer, Mr. Keyte, was more zealous than his predecessor, Mr. Maskell, and there was a brief increase in prosecutions in 1901 and 1902.

Although the strong religious non-conformity of Leicester has often been put forward as a major local factor, I feel this was untrue as far as vaccination itself was concerned. ${ }^{57}$ Religious objections to vaccination were used by individuals, but no one group officially rejected it. Religion may have been a factor in the fight against the compulsion of the acts. It should be noted that the townspeople accepted the Public Health Acts, Notification Act, and other health legislation.

Another and probably major factor which gave support to the Leicester antivaccinationists, was Johnston's system of containing smallpox (1877). This provided an alternative. Johnston, who was a firm believer in vaccination, yet admitting there were risks, devised his method alone. He unified the town's existing facilities and added quarantine and compulsory notification. ${ }^{58}$ During his first years in practice in the town, the cause had undergone a revitalization. It could be suggested that his system confined smallpox amongst the poorer classes, where the disease presented its greatest threat, and the anti-vaccinationists were most active. These were also the people who would make most effective use of the Fever Hospital. In later years it is on record that Johnston felt that if the whole country were to use the Leicester Method the severity of the Vaccination Acts might be relaxed. Equally he considered that some of the antivaccinationists were dishonest or had sinister motives. ${ }^{59}$

The anti-vaccinationists subsequently put forward the Johnston System or Leicester Method as an alternative to vaccination to the people of Leicester and later to the Royal Commission of 1889-1897, which took evidence from the Leicester delegation in 1891. Their obsession in trying to remove compulsory infant vaccination omitted to acknowledge the protective value of vaccination itself.

It is surprising to find on detailed study of the contemporary reports that at the height of the agitation against the Vaccination Acts, Dr. Tomkins ensured that he and his staff were vaccinated, and he offered vaccination to quarantinees. Dr. Priestley tried to do the same on a larger scale, but the officials were by then hardened antivaccinationists. They felt they could do away with vaccination completely, and it was not until 1901 that Dr. Millard could use vaccination openly and efficiently in conjunction with the Leicester Method.

56 Biggs, op. cit., note 23 above, p. 89.

57 J. Simmons, A view of Leicester, Leicester University Press, 1974, p. 18.

58 At the Council meeting to decide on the Assistant Medical Officer of Health's post, the majority wished to appoint someone in practice in the town, who believed in rapid isolation of potentially epidemic diseases, partly to maximize the use of the Fever Hospital. Johnston supported this view. Leicester Daily Post, 24 April and 1 June 1877.

59 Ibid., 1876. Correspondence columns contain many letters written under pseudonyms, rarely revealing the real identity. "McShane", correspondence, $20 \mathrm{July}$, is known to be Johnston - he here suggested that some of the anti-vaccinationists were dishonest. Family scrapbook; also [Special Commissioner] 'Leicester and its immunity from smallpox', Lancet, 1886, i: 1091. 


\section{Stuart M. F. Fraser}

I feel the influence of the anti-vaccinationists, although important in Leicester, confuses the issue. The protagonists always polarized violently into those who felt vaccination was the only salvation from smallpox, and those who considered it the work of the devil, and relied on good sanitation and general health management to combat the disease. The Leicester Method was devised and advised by a person believing in the value of vaccination, but realizing its limitations, and probably thinking of a particular at-risk group. The method was established in Leicester before the anti-vaccinationists became a major influence there. I do not deny that they were present especially following the 1871-72 epidemic, but they were not the major reason why Dr. Johnston devised his system. Hospital provision, the new germ theories, the unification of the various health facilities of the town, and his insistence on universal notification and quarantine of contacts were all important. It was unfortunate that the anti-vaccinationists felt the method could survive without vaccination, although, as I have shown, selective vaccination was certainly used to some extent from 1886 to 1893 , when the anti-vaccinationist movement was at its height. Tragedies occurred, and it was not until 1901 that Leicester people were able to accept the principles of the Leicester Method to protect the community and vaccination to protect the individual.

\section{SUMMARY}

The eradication of smallpox from the world is one of the major achievements of medical science and public health. Leicester contributed significantly to this. In 1877 a system was devised on the advice of the Assistant Medical Officer of Health, Dr. William Johnston, which confined all smallpox cases and their contacts, by compulsory notification. An enlightened Town Council provided a relatively large hospital which admitted all cases where they could receive professional nursing care. Dr. Johnston had appeared at the correct time, he was able to unify the existing facilities, and add the need for compulsory notification, and quarantine. It is uncertain where Johnston gained his earlier experience and interest in epidemic diseases, but it is certain that he represented the newer generation of doctors believing in "germs" and prepared to apply the new scientific techniques to medicine and public health, so ousting the older generation of doctors, including his predecessor Dr. Crane, who still believed in miasmatic theories.

The Victorian Vaccination Acts were shown to be impractical and inadequate alone, see the experience of Warrington or Sheffield. The success of Johnston's System was recognized by the anti-compulsory infant vaccination movement in the town, who adopted the system as an alternative to all vaccination with some tragic consequences. Later modification of the Vaccination Acts, improved vaccination, and better understanding of the disease eventually enabled the people of Leicester to accept the Leicester Method to protect the community and vaccination to protect the individual.

There are interesting and close similarities between the Leicester Method as developed in 1877, and current health care methods, ${ }^{60}$ and also the final phase of the W.H.O. Smallpox Eradication Programme.61

60 F. G. Davies (editor), Clays handbook of environmental health, London, Lewis, 1977, pp. 424 and 426. Cf. Alderman Windley's statement ". . . . and as to the cordon of protected persons that is a matter for the officer of health . . .". T. Windley, 'Correspondence', Lancet, 1886, i: 1141.

61 D. A. Henderson, 'The eradication of smallpox', Sci. Am. , 1976, 235: 31-32. 